\title{
PENYELESAIAN KLAIM PERJANJIAN ASURANSI SECARA EX GRATIA \\ DITINJAU DARI UNDANG-UNDANG NOMOR 4O TAHUN 2014 TENTANG PERASURANSIAN DAN UNDANG-UNDANG NOMOR 30 TAHUN 1999 TENTANG ARBITRASE DAN ALTERNATIF PENYELESAIAN SENGKETA
}

\author{
RA Diah Irianti Permana Sari
}

Fakultas Hukum Universitas Pamulang

diahir73@yahoo.com

\begin{abstract}
Insurance is an agreement to be responsible to bear the obligation in which the insurer is willing to provide compensation to the insured in case of loss to the object of coverage in accordance the premium. The agreement between the insured and the insurer is written in a written certificate called the policy. The insurance policy must comply with the provisions set forth in the Indonesian Civil Code (Criminal Code) Article 1320 stating that for the validity of a treaty, four conditions are required, namely, those who commit themselves, are competent to make agreement, a certain matter and halal causes. If disputes arise between the parties, the settlement of dispute may be conducted in court (litigation) and outside court (non litigation). According to the Constitution Number 40 Year 2014 about Insurance and Constitution Number 30 about Arbitration and Alternative Dispute Settlement, ex gratia of settlement does not deviate from the provisions mentioned in the two Constitution, so there is no violation of the law conducted by the parties if this way is taken.
\end{abstract}

Keyword: Agreement, Insurance, Claim and Ex Gratia.

\begin{abstract}
ABSTRAK
Asuransi adalah perjanjian tanggung menanggung dimana penanggung bersedia memberikan ganti rugi kepada tertanggung jika terjadi kerugian terhadap objek pertanggungan sesuai dengan syarat dan ketentuan polis dan sebagai kompensasi atas tanggung jawab yang dipikul, penanggung berhak menerima pembayaran sejumlah uang dari tertanggung yang disebut dengan premi. Perjanjian antara tertanggung dan penanggung di tuangkan dalam suatu akta tertulis yang disebut polis. Polis asuransi harus memenuhi ketentuan yang diatur dalam Kitab Undang-Undang Hukum Perdata (KUHPer) Pasal 1320 yang menyatakan bahwa untuk sahnya suatu perjanjian diperlukan empat syarat yaitu, sepakat mereka yang mengikatkan dirinya, cakap untuk membuat suatu perikatan, suatu hal tertentu dan suatu sebab yang halal. Jika timbul sengketa antara para pihak, penyelesaian sengketa dapat dilakukan melalui jalur pengadilan (litigasi) dan diluar pengadilan (non litigasi). Ditinjau dari Undang-Undang Nomor 40 Tahun 2014 Tentang Perasuransian dan Undang-Undang Nomor 30 Tahun 1999 Tentang Arbitrase dan Alternatif Penyelesaian Sengketa penyelesaian klaim secara ex gratia tidak menyimpang dari ketentuan yang tercantum dalam kedua undang-undang tersebut,sehingga tidak ada pelanggaran hukum yang dilakukan oleh para pihak jika cara ini yang ditempuh.
\end{abstract}

Kata Kunci : Perjanjian, Asuransi, Klaim dan Ex Gratia. 


\section{PENDAHULUAN}

Dalam hidup manusia selalu dihadapkan pada suatu risiko. Risiko berasal dari suatu kemungkinan (propability), termasuk hal yang tidak diharapkan. Risiko dapat datang secara tiba-tiba dan tak terduga dan dapat mengakibatkan kerugian baik kerugian keuangan (financial), raga, kehormatan bahkan kerugian jiwa.

Dengan semakin berkembangnya peradaban manusia maka risiko yang dihadapi juga semakin beragam (complex). Manusia sebagai mahluk yang diberikan akal budi oleh Tuhan Yang Maha Esa, berpikir untuk dapat meminimalisasikan risiko yang akan dihadapinya dengan cara melakukan perikatan dengan perusahaan asuransi yang disebut perjanjian asuransi.

Asuransi adalah istilah yang digunakan untuk merujuk pada tindakan, sistem, atau bisnis dimana perlindungan finansial (atau ganti rugi secara finansial) untuk jiwa, properti, kesehatan dan lain sebagainya mendapatkan penggantian dari kejadiankejadian yang tidak dapat diduga yang dapat terjadi seperti kematian, kehilangan, kerusakan atau sakit, dimana melibatkan pembayaran premi secara teratur dalam jangka waktu tertentu sebagai ganti polis yang menjamin perlindungan tersebut.

Menurut Undang-Undang No.2 Tahun 1992 Pasal 1 : "Asuransi atau pertanggungan adalah perjanjian antara dua pihak atau lebih, dengan mana pihak Penanggung mengikatkan diri kepada tertanggung, dengan menerima premi asuransi, untuk memberikan penggantian kepada tertanggung karena kerugian, kerusakan atau kehilangan keuntungan yang diharapkan, atau tanggung jawab hukum kepada pihak ketiga yang mungkin akan diderita tertanggung yang timbul dari suatu peristiwa yang tidak pasti, atau untuk memberikan suatu pembayaran yang didasarkan atas meninggal atau hidupnya seseorang yang dipertanggungkan”.

Didalam asuransi terdapat hukum hukum asuransi yaitu :

Asuransi dalam Undang-Undang No.2 Th 1992 Asuransi dalam Undang-Undang No.2 Th 1992 tentang usaha perasuransian adalah perjanjian antara dua pihak atau lebih, dengan mana pihak penanggung mengikatkan diri kepada tertanggung, dengan menerima premi asuransi, untuk memberikan penggantian kepada tertanggung karena kerugian, kerusakan atau kehilangan keuntungan yang diharapkan atau tanggung jawab hukum pihak ke tiga yang mungkin akan diderita tertanggung, yang timbul dari suatu peristiwa yang tidak pasti, atau memberikan suatu pembayaran yang didasarkan atas meninggal atau hidupnya seseorang yang dipertanggungkan.

Badan yang menyalurkan risiko disebut "tertanggung", dan badan yang menerima risiko disebut "penanggung". Perjanjian antara kedua badan ini disebut kebijakan: ini adalah sebuah kontrak legal yang menjelaskan setiap istilah dan kondisi yang dilindungi. Biaya yang dibayar oleh "tetanggung" kepada "penanggung" untuk risiko yang ditanggung disebut "premi". Ini biasanya ditentukan oleh "penanggung" untuk dana yang bisa diklaim di masa depan, biaya administrative dan keuntungan.

Contohnya, seorang pasangan membeli rumah seharga Rp. 100 juta. Mengetahui bahwa kehilangan rumah mereka akan membawa mereka kepada kehancuran finansial, mereka mengambil perlindungan asuransi dalam bentuk kebijakan kepemilikan rumah. Kebijakan tersebut akan membayar penggantian atau perbaikan rumah mereka bila terjadi bencana. Perusahaan asuransi mengenai mereka premi sebesar Rp1 juta per tahun. Risiko kehilangan rumah telah disalurkan dari pemilik rumah ke perusahaan asuransi.

Perjanjian adalah perbuatan hukum yang terjadi sesuai dengan formalitasformalitas dari peraturan hukum yang ada, tergantung dari persesuaian kehendak dua atau lebih orang yang ditujukan untuk timbulnya akibat hukum demi kepentingan salah satu pihak atas beban pihak lain atau demi kepentingan dan atas beban masingmasing pihak secara timbal balik.(Patrick,1996).

Kitab Undang-Undang Hukum Perdata (KUHPer) Pasal 1313 hampir sama dengan pandangan Setiawan, beliau menyatakan bahwa, perjanjian adalah suatu perbuatan hukum dimana satu orang atau 
lebih mengikatkan dirinya atau saling mengikatkan dirinya terhadap satu orang atau lebih.(Setiawan,1979).

Sedangkan Menurut Syahmin. AK bahwa dalam bentuknya perjanjian itu berupa suatu rangkaian perkataan yang mengandung janji-janji atau kesanggupan yang diucapkan atau ditulis.(Syahmin,2006).

R. Subekti menyimpulkan bahwa perikatan adalah suatu hubungan hukum antara dua orang atau dua pihak, berdasarkan mana pihak yang satu berhak menuntut suatu hal dari pihak yang lain dan pihak yang lain berkewajiban untuk memenuhi kebutuhan tersebut.(Subekti,1987).

Perjanjian asuransi juga merupakan perikatan dimana para pihak saling berjanji dan menyepakati adanya perbuatan hukum yang menimbulkan hak dan kewajiban. Syarat sahnya perjanjian harus juga dipenuhi dalam pejanjian asuransi.

Syarat sah nya suatu perikatan menurut pasal 1320 KHUPer ( Kitab Undang-Undang Hukum Perdata) tidaklah menyatakan bahwa perikatan harus dinyatakan secara tertulis sehingga perikatan secara lisan pun sepanjang memenuhi syarat sahnya suatu perjanjian maka berlaku mengikat para pihak.Perdata yang mengharuskan suatu perjanjian dibuat secara tertulis". Dengan kata lain, suatu Perjanjian yang dibuat secara tidak tertulis juga mengikat secara hukum bagi para pihak yang membuatnya (Aan,2018).

Meskipun sahnya perjanjian atau perikatan tidaklah wajib tertulis, namun berdasarkan pasal 255 Kitab UndangUndang Hukum Dagang (KUHD) mewajibkan perjanjian asuransi harus dinyarakan secara tertulis dalam akta yang disebut polis.

Dalam perikatan antara tertanggung dan penanggung, kesepakatan para pihak, baik yang mengalihkan risiko dan yang menerima pengalihan risiko menjadi dasar suatu perjanjian atau kontrak asuransi. Perjanjian atau kontrak asuransi dikenal dengan nama polis. Uang sebagai hasil kompensasi tersebut dikenal dengan nama "premi". Pihak yang melakukan pengalihan risiko disebut "tertanggung" dan pihak yang menerima pengalihan risiko disebut "penanggung".
Karena perjanjian asuransi haruslah tertulis sehingga dapat dikategorikan sebagai kontrak antara tertanggung dan penanggung, maka sebelum adanya kesepakatan pastilah ada permintaan dan penawaran.

Prinsip dasar lahirnya suatu kontrak adalah adanya offer (penawaran) dan acceptance (penerimaan) untuk memastikan proses offer dan acceptance ini supaya tidak menimbulkan masalah hukum dimasa yang akan datang maka perlu diperhatikan pihak yang memberikan penawaran dan yang menerima penawaran memiliki itikad baik dan kepercayaan dalam membuat kontrak selain tentunya kecakapan dan kewenangan yang dimiliki.(Siti,2019).

Tertanggung hanya boleh memperoleh ganti rugi sebesar kerugian yang dideritanya, artinya tertanggung tidak boleh mencari keuntungan dari asuransi. Begitu juga dengan penanggung, tidak boleh mencari keuntungan atas interest yang ditanggungnya, kecuali memperoleh balas jasa atau premi. (Radiks,1995).

Risiko-risiko yang bersifat tidak pasti dalam waktu dekat atau akan terjadi dikemudian hari dan apabila risiko terjadi tidak diketahui kerugian yang akan ditimbulkannya secara ekonomis. Salah satu cara adalah dengan mengalihkan risiko tersebut kepada pihak lain diluar diri manusia itu sendiri (transfer of risk).(Suparman, 2003).

Untuk mengurangi atau menghilangkan beban risiko tersebut, pihak tertanggung berupaya mencari jalan keluar mengalihkan risiko kepada pihak lain dengan membayar kotra prestasi yang disebut premi kepada penanggung.(Abdul Kadir,2011).

Tidak semua hal dapat diasuransikan dan tidak semua kerugian bisa mendapatkan penggantian, kewajiban masing-masing pihak yang telah disepakati harus dipenuhi sebelum menuntut haknya, hal inilah menjadi salah satu penyebab terjadinya sengketa asuransi.

Sengketa terjadi pada umumnya disebabkan oleh ketidakpahaman tertanggung tentang isi polis atau penanggung tidak memberikan penjelasan mengenai syarat dan kondisi polis kepada tertanggung. Dapat juga karena faktor 
kesengajaan tertanggung untuk menutupi kondisi objek pertanggungan yang sebenarnya (un discloser) atau saat terjadi kerugian tertanggung belum melakukan pembayaran premi dan telah melewati masa tenggang waktu pembayaran (warranty payment clause).

Undang-Undang Nomor 40 Tahun 2014 Tentang Perasuransian Pasal 1 butir (25) menyatakan bahwa objek yang dapat dipertanggungkan dalam usaha perasuransian meliputi : jiwa dan raga, kesehatan manusia, tanggung jawab hukum, benda dan jasa serta semua kepentingan lainnya yang dapat hilang, rusak, rugi dan / atau berkurang nilainya.

Adapun bentuk badan hukum penyelenggaraan usaha perasuransian yang diperkenankan di Indonesia menurut Undang-Undang Nomor 40 Tahun 2014 Tentang Perasuransian Pasal 6 adalah perseroan terbatas, koperasi dan usaha bersama yang telah ada pada saat undangundang ini diundangkan.

Perusahaan asuransi di Indonesia berdasarkan Pasal 5 butir (1) UndangUndang Nomor 40 Tahun 2014 Tentang Perasuransian memiliki ruang lingkup yaitu : Usaha Asuransi Umum, Usaha Asuransi Jiwa, Usaha Asuransi Umum Syariah dan Usaha Asuransi Jiwa Syariah.

Semakin banyak perjanjian/kontrak asuransi dibuat otomatis akan banyak pula kemungkinan terjadi tuntutan klaim dan sengketa perjanjian asuransi yang terjadi.

Di Indonesia hukum normatif memperkenankan penyelesaian sengketa dilakukan melalui proses peradilan (litigasi) atau diluar pengadilan (non litigasi). Proses penyelesaian sengketa perjanjian atau kontrak asuransi pada prinsipnya memberikan kebebasan yang menguntungkan para pihak, sepanjang para pihak sepakat memilih proses penyelesaiannya.

Bagir Manan mengemukakan bahwa penegakan hukum sebagai bentuk konkrit penerapan hukum sangat mempengaruhi secara nyata perasaan hukum, kepuasan hukum, manfaat hukum atau keadilan hukum secara individu atau sosial.(Sukardana, 2011)

Menurut Mariam Darus Badrulzaman dalam hukum perjanjian terdapat 10 (sepuluh) asas, yaitu asas kebebasan berkontrak, asas konsensualisme, asas kepercayaan, asas kekuatan mengikat, asas kepastian hukum, asas moral, asas persamaan hukum, asas keseimbangan, asas kepatutan, asas kebiasaan. Selain kesepuluh asas tersebut, ada pula ahli yang memasukkan asas itikat baik sebagai asas dalam perjanjian.(Neo, 2009)

Rasa keadilan tidak hanya dapat diperoleh melalui penyelesaian secara litigasi saja, tetapi juga dapat diperoleh melalui non litigasi baik secara negosiasi, mediasi, konsiliasi atau melalui badan arbitrase (Alternative Dispute Resolution).

Usaha memaksimalkan perdamaian dalam sengketa merupakan upaya untuk menyempurnakan proses perdamaian sebagaimana dinyatakan dalam HIR/Rbg yang semata-mata bersifat formalitas, karena tidak difasilitasi oleh peradilan/hakim. Hal ini merupakan proses pergaulan hidup global khususnya dalam hubungan ekonomi atau bisnis antar negara-negara di dunia yang menghendaki adanya penyelesaian alternative jika timbul suatu sengketa bisnis.(Cecep, 2012).

Penyelesaian klaim pejanjian asuransi secara negosiasi karena klaim yang tidak terjamin (unclaimable) salah satunya melalui penyelesaian klaim secara ex gratia, penyelesaian ini belum banyak diketahui oleh masyarakat luas. Aturan hukum normatif yang ada di Indonesia belum menyatakan secara tegas dan jelas (explisit) prosedur penyelesaian klaim perjanjian asuransi secara kebijaksanaan (ex gratia) dapat dilaksanakan.

Dalam Undang-Undang Nomor 40 Tahun 2014 Tentang Perasuransian dan Undang-Undang Nomor 30 Tahun 1999 Tentang Arbitrase dan Alternatif Penyelesaian Sengketa tidak mengatur tehnis pelaksanaan penyelesaian klaim perjanjian asuransi secara kebijaksanaan (ex gratia), hanya ketentuan yang tercantum dalam pasal 31 butir (3) dan (4) UndangUndang Nomor 40 Tahun 2014 Tentang Perasuransian, dimana perusahaan asuransi diwajibkan untuk menanggani klaim dan keluhan melalui proses yang cepat sederhana, mudah diakses dan adil, serta perusahaan asuransi dilarang melakukan tindakan yang dapat memperlambat 
penyelesaian atau pembayaran klaim. Penggunaan asuransi tentu sudah tidak asing lagi bagi kebanyakan orang, mengingat jumlah pengguna asuransi semakin hari semakin tinggi di Indonesia. Tingginya pengguna asuransi ini didominasi oleh berbagi macam produk asuransi seperti asuransi jiwa, asuransi kesehatan, serta asuransi perlindungan harta (mobil, rumah, dll).

Kesadaran masyarakat akan pentingnya asuransi telah semakin tinggi. Namun hal tersebut tidak serta merta membuat semua pengguna asuransi mengerti mengenai apa sebenarnya manfaat dan keuntungan yang didapatkan dalam asuransi yang digunakan oleh mereka, hal ini bisa terjadi akibat kurangnya pemahaman mengenai ketentuan serta kebijakan yang ditetapkan di dalam asuransi itu sendiri.

Dalam beberapa kasus, kita seringkali menemukan nasabah yang kecewa dan merasa dirugikan akibat penggunaan asuransi yang dirasa tidak maksimal dan tidak sesuai dengan harapan mereka, di mana pada dasarnya hal seperti ini bisa saja terjadi akibat kurangnya pemahaman kita pada semua pasal serta peraturan yang sebenarnya "wajib" kita pahami sebelum memutuskan untuk menggunakan asuransi.

Sehubungan dengan hal ini perlu dilakukan kajian hukum penyelesaian klaim perjanjian asuransi secara ex gratia ini apakah telah memenuhi ketentuan asas negara hukum, bersifat adil bagi para pihak dan cara penyelesaian klaim ini memberikan kemanfaataan serta dapat memberikan keberhasilan dalam penyelesaian bagi para pihak. Penyelesaian klaim perjanjian asuransi secara kebijaksanaan (ex gratia) banyak ditempuh oleh perusahaan asuransi namun belum banyak dipahami oleh masyarakat.

\section{METODE PENELITIAN}

Metode penelitian hukum yang digunakan adalah secara empiris, normatif dan kualititatif, data primer yang diperoleh langsung dari sumber pertama, juga dilakukan wawancara / interview dengan pihak yang memiliki kompetensi pada sebuah perusahaan asuransi umum nasional di Jakarta. Data sekunder diambil dari dokumen resmi, buku-buku, hasil penelitian yang berwujud laporan dan juga bahan hukum tersier yang memberikan petunjuk maupun penjelasan terhadap bahan hukum primer dan sekunder diantaranya majalah, surat kabar dan informasi yang diakses melalui media internet. Kemudian data tersebut dianalisa dengan membuat deskripsi atau gambaran-gambaran faktafakta hukum yang terjadi dilapangan atau dilaksanakan oleh para pihak untuk menyelesaikan klaim perjanjian asuransi dan dikaitan dengan filsafat hukum, teori-teori hukum dan kaidah-kaidah hukum dan kemudian dikaitkan juga dengan peraturan perundangan-undangan yang berlaku di Indonesia ( $d a$ sollen) sehingga diperoleh jawaban atas permasalahan yang dirumuskan.

\section{PERMASALAHAN}

Untuk memberikan arahan pada penulis dalam melakukan penelitian ini maka dirumuskanlah permasalahan berkaitan dengan bagaimana penyelesaian klaim perjanjian asuransi secara ex gratia merupakan bagian dari penyelesaian sengketa secara non litigasi dan jika ditinjau dari Undang-Undang Nomor 40 Tahun 2014 Tentang Perasuransian dan Undang-Undang Nomor 30 Tahun 1999 Tentang Arbitrase dan Alternatif Penyelesaian Sengketa beserta dengan faktornya?

\section{PEMBAHASAN}

Beberapa faktor penyebab penyelesaian klaim perjanjian asuransi diiselesaikan secara ex gratia diantaranya adalah tertanggung merupakan nasabah loyal (telah mengcover asuransi pada penanggung yang sama selama bertahun tahun), tertanggung merupakan priority customer, yaitu nasabah yang telah memberikan kontribusi premi yang besar bagi penanggung dan tertanggung memiliki prospek bisnis kedepan yang baik dan menjanjikan.Dengan pertimbangan hubungan baik yang terbina selama ini, atau untuk menghindarkan kasus berlanjut ke meja pengadilan, maka penanggung membayarkan klaim tersebut dengan basis ex gratia. 
Klaim perjanjian asuransi yang penyelesaiannya secara ex gratia biasanya pembayaran tidak dilakukan secara penuh (full payment) sebesar nilai claim adjustment atau kerugian keuangan yang benar-benar dialami oleh tertanggung, tetapi lebih rendah dan berdasarkan persetujuan dari penanggung.

Kelebihan dari penyelesaian sengketa klaim perjanjian asuransi secara ex gratia adalah efisien biaya jika dibandingkan dengan penyelesaian klaim diluar pengadilan yang lainnya seperti mediasi, konsiliasi atau arbitrase. Karena dengan melibatkan pihak ketiga baik itu mediator maupun arbiter tentunya akan ada biaya tambahan yang harus dikeluarkan sebagai fee untuk mediator atau arbiter, efisien waktu, karena penyelesaian ini lebih bersifat negosiasi antara para pihak yang bersengketa maka agenda penyelesaiannya akan lebih mudah dan cepat, kerahasian lebih terjaga karena penyelesaian hanya dilakukan oleh para pihak yang bersengketa, untuk pelaku bisnis termasuk perasuransian hal ini dapat menjaga citra / image perusahaan di masyarakat, pelaksanaan penyelesaian akan lebih yakin atau pasti, karena merupakan hasil kesepakatan para pihak dan para pihak akan merasakan tidak ada yang kalah atau menang (win win solution). Dalam bisnis perasuransian hal ini dapat meningkatkan hubungan baik antara tertanggung dan penangung serta meningkatkan kepercayaan tertanggung kepada penanggung. Penanggung akan mendapatkan dampak positif dengan timbulnya kepercayaan dari tertanggung yang memungkinkan bertambahnya prospek bisnis ke depan baik dari tertanggung sendiri maupun dari rekanan tertanggung, karena jaringan bisnis serta kepercayaan merupakan modal dasar bagi suatu perusahaan asuransi dapat meningkatkan bisnisnya

Hasil penelitian dan data yang diperoleh dari sumber pertama melalui wawancara /interview jika dihubungkan dengan kaidah -kaidah hukum serta teori teori hukum maka diperoleh kesimpulan bahwa penyelesaian klaim perjanjian asuransi secara ex gratia ditinjau dari Undang-Undang Nomor 40 Tahun 2014 Tentang Perasuransian dan Undang -
Undang Nomor 30 Tahun 1999 Tentang Arbitrase dan Alternatif Penyelesaian Sengketa telah memenuhi teori keadilan untuk penanggung dan tertanggung (para pihak) karena penyelesaian klaim cara ini merupakan hasil kesepakatan sehingga tidak ada yang merasa dikalahkan atau dimenangkan (win-win solution) .

Berdasarkan teori kemanfaatan hukum (utilitariarisme) bahwa penyelesaian klaim perjanjian asuransi secara ex gratia memberikan kemanfaatan bagi para pihak dalam memecahkan masalah klaim . Sedangkan berdasarkan teori kepastian hukum meskipun penyelesaian klaim perjanjian asuransi secara ex gratia, tidak diatur secara eksplisit dalam UndangUndang Nomor 40 Tahun 2014 Tentang Perasuransian, namun tersirat dalam bunyi Pasal 31 ayat 3 yang menyatakan bahwa "Perusahaan asuransi, perusahaan asuransi syariah, perusahaan reasuransi, perusahaan reasuransi syariah, perusahaan pialang asuransi dan perusahaan pialang reasuransi syariah wajib menangani klaim dan keluhan melalui proses yang cepat, sederhana, mudah diakses dan adil", sehingga secara tidak langsung bahwa penyelesaian klaim perjanjian asuransi secara ex gratia merupakan salah satu upaya penanggung dalam menyelesaikan klaim secara cepat, mudah dan adil.

Sedangkan dalam Undang-Undang Nomor 30 Tahun 1999 Tentang Arbitrase dan Alternatif Penyelesaian Sengketa juga tidak mengatur secara spesifik tentang penyelesaian klaim perjanjian asuransi secara ex gratia namun dapat tercermin dalam bunyi Pasal 6 ayat 1 yang menyatakan bahwa "Penyelesaian sengketa atau beda pendapat perdata dapat diselesaikan oleh para pihak melalui alternatif penyelesaian sengketa yang didasarkan pada itikat baik dengan mengesampingkan penyelesaian secara litigasi di Pengadilan", artinya jika terjadi sengketa klaim maka para pihak berdasarkan pasal ini dapat menyelesaikan dengan itikat baik dan sepanjang tidak melanggar hukum normatif yang berlaku. Dalam dunia bisnis atau perdagangan selain terdapat aturan hukum yang tertulis (normative) terdapat juga hukum kebiasaan yang digunakan sebagai dasar para pelaku bisnis untuk menyelesaikan masalah. 
Penyelesaian klaim perjanjian asuransi secara kebijaksanaan (ex gratia) ini merupakan bentuk hukum kebiasaan dalam bisnis perasuransian dalam menyelesaikan banding klaim asuransi yang diajukan oleh tertanggung.

Sehingga berdasarkan teori hukum keberhasilan bahwa penyelesaian klaim perjanjian asuransi secara kebijaksanaan (ex gratia) diakui dapat memenuhi teori keberhasilan, dimana banyak kasus banding klaim yang diajukan oleh tertanggung dapat terselesaikan dengan baik (win win solution).

Dalam Pasal 6 ayat (2) UndangUndang Nomor 30 Tahun 1999 Tentang Arbitrase dan Alternatif Penyelesaian Sengketa, menyatakan bahwa "Kesepakatan penyelesaian sengketa atau beda pendapat secara tertulis adalah final dan mengikat para pihak untuk dilaksanakan dengan itikad baik serta wajib didaftarkan di Pengadilan negeri dalam waktu paling lama 30 (tiga puluh) hari sejak penandatanganan", artinya dengan penandatangan kesepakatan penyelesaian sengketa dapat menjadi dasar kepastian hukum bagi para pihak, dengan tetap menjaga itikat baik (ut most good faith), sehingga memenuhi teori kepastian hukum. Dari uraian diatas bahwa penyelesaian klaim perjanjian asuransi secara ex gratia dapat memenuhi asas kemanfaatan , teori keberhasilan hukum dan teori kepastian hukum serta tidak ada pelanggaran terhadap undang-undang yang berlaku di Indonesia.

\section{PENUTUP}

\section{Kesimpulan}

Bahwa penyelesaian klaim perjanjian asuransi secara ex gratia merupakan bagian dari penyelesaian sengketa secara non litigasi dan jika ditinjau dari UndangUndang Nomor 40 Tahun 2014 Tentang Perasuransian dan Undang-Undang Nomor 30 Tahun 1999 Tentang Arbitrase dan Alternatif Penyelesaian Sengketa, tidak ada hal yang dilanggar dan tidak juga melanggar norma hukum lain yang berlaku di Indonesia. Beberapa faktor penyebab penyelesaian klaim perjanjian asuransi secara ex gratia adalah lebih efisien, pelaksanaannya akan lebih baik hasilnya karena merupakan kesepakatan para pihak, menjaga hubungan bisnis khususnya nasabah prioritas (priority customer), mempertahankan account bisnis yang sudah ada, menjaga good image perusahaan serta guna memberikan peluang serta prospek bisnis ke depan khususnya dalam hal rekomendasi bisnis dari nasabah kepada relasinya.

\section{Saran}

Diharapkan pemerintah dapat menambahkan pasal dalam Undang-Undang Nomor 40 Tahun 2014 Tentang Perasuransian untuk mengatur secara garis besar mengenai syarat dan ketentuan penyelesaian klaim perjanjian asuransi secara ex gratia tentang kebijakan pembayaran klaim secara ex gratia, guna menghindari pertimbangan yang tidak relevan. Diharapkan meskipun penyelesaian klaim perjanjian asuransi secara ex gratia bersifat akomodasi bisnis namun penanggung juga dapat memberikan kebijakan penyelesaikan klaim secara ex gratia kepada nasabah yang bersifat sosial, seperti : yayasan sekolah, mesjid, gereja atau sarana umum masyarakat lain sebagai bagian dari kepedulian sosial perusahaan asuransi kepada masyarakat sebagai bagian dari Corporate Social Responbility (CSR).

\section{DAFTAR PUSTAKA}

Aan Handriyani, " Keabsahan Perjanjian Jual Beli Secara Tidak Tertulis Berdasarkan Hukum Perdata”, Volume 1, Rechsregel Jurnal Ilmu Hukum Universitas Pamulang, 2018.

Abdul Kadir, "Hukum Asuransi Indonesia", (Bandung : PT Citra Aditya, 2011).

Cecep R,"Tinjauan Komparatif Hukum Penyelesaian Sengketa Perjanjian Ekonomi Syariah Ditinjau dari Undang - Undang No. 3o Tahun 1999 Tentang Arbitrase dan Alternatif Penyelesaian Sengketa" (Pada Pengadilan Agama Cibadak, Universitas Pamulang, 2012).

Imade Sukardana, "Mediasi Dalam Sistem Peradilan Perdata Indonesia Dalam Rangka Mewujudkan Proses Peradilan Yang Sederhana, Cepat dan Biaya Ringan", (Jakarta: Prestasi Pustaka, 2012). 
Kitab Undang-Undang Hukum Dagang (KUHD).

Kitab Undang-Undang Hukum Perdata (KUHPer).

M. Suparman Sastrawidjaja, "Aspek - Aspek Hukum Asuransi dan Surat Berharga", (Bandung: PT Alumni Bandung, 2003).

Neo Wiletno, "Pelaksanaan Hak dan Kewajiban Para Pihak Dalam Perjanjian Asuransi Kecelaaan Diri PT Asuransi Jasindo," (Semarang: Universitas Diponegoro, 2009).

Patrick Puwahid," Hukum Perdata”, (Semarang: $\quad \mathrm{FH}$ Universitas Diponegoro, 1996).

Peraturan Perundang - undangan Republik Indonesia Nomor 40 Tahun 2014 Tentang Perasuransian.

Peraturan Perundang-undangan Republik Indonesia Nomor 30 Tahun 1999 Tentang Arbitrase dan Alternatif Penyelesaian Sengketa.

R.Subekti,“ Hukum Perjanjian”, (Jakarta: PT Citra Adhitya, 1987).

Radiks Purba, "Memahami Asuransi di Indonesia", (Jakarta: Lembaga Pendidikan dan Pembinaan Manajemen, 1995).

Setiawan, "Pokok-Pokok Hukum Perikatan", (Bandung : Alumni, 1979).

Siti Nurwulan et al, "Aspek Normatif Asas Konsensualisme Dalam Penambahan Kluasula Kontrak Tanpa Persetujuan Para Pihak" Volume 2, Rechsregel, Jurnal Ilmu Hukum Universitas Pamulang, 2019.

Syahmin, "Hukum Kontrak International", (Jakarta: Raja Grafindo, 2006). 